\title{
Newly recorded ferns from the flora of Myanmar in Natma Taung National Park
}

\author{
Thet Yu NWE, Myung-Ok MOON ${ }^{1}$, Seung-Hoon LEE $^{2}$ and Byung-Yun SUN ${ }^{3 *}$ \\ Department of Botany, Yangon University, Yangon 11041, Myanmar \\ ${ }^{I}$ Research Institute of Basic Sciences, Jeju National University, Jeju 63243, Korea \\ ${ }^{2}$ Endangered Species Restoration Technology Institute, Korea National Park Service, Yeongju 36015, Korea \\ ${ }^{3}$ Department of Life Sciences, Chonbuk National University, Jeonju 54896, Korea \\ (Received 15 November 2018; Revised 11 January 2019; Accepted 19 March 2019)
}

\begin{abstract}
Although Myanmar is a biodiversity hotspot, little is known about its flora, particularly lycophytes and ferns, due to a lack of intensive inventories. In 2017, work on a total of 299 species of lycophytes and ferns found throughout the country, including 84 species from Natma Taung National Park in the Chin State, was published. However, a comparison of the flora of Myanmar with those of adjacent countries suggests that many more species are likely also to be distributed in this country. In the present study, two field surveys conducted in Natma Taung National Park during 2015 to make a checklist of lycophytes and ferns resulted in the discovery of three fern species not previously recorded in the flora of Myanmar. All occur in other countries in Southeast Asia as well as in other tropical areas. These species are Pteris bella (Pteridaceae), Dryopteris lepidopoda (Dryopteridaceae), and Loxogramme duclouxii (Polypodiaceae). The results will provide valuable information for the Myanmar fern checklist that is currently being prepared.
\end{abstract}

Keywords: Natma Taung National Park, Myanmar, new record, ferns

Myanmar is one of the largest countries in Southeast Asia and is a biodiversity hotspot, which is expected to have a very high level of plant diversity. Before Dickason (1946) published the first comprehensive flora of lycophytes and ferns of Myanmar, most early botanical activities focused either solely on flowering plants or enumerated lycophytes and ferns sporadically as part of the exploration of flowering plants (Kurz, 1877; Merrill, 1941). A number of factors, including insufficient manpower, sparse literature, and lack of voucher specimens, have prevented the detailed enumeration of the flora of Myanmar. Dickason (1946) reported 460 species belonging to 104 genera. Subsequently, Bell (1953) reported 46 species of lycophytes and ferns from the Yangon-Insein Region. More recently, Thet (2003) and Nwe (2009) reported a number of lycophytes and ferns from Myanmar. In 2016, Nwe et al. (2016) reported five unrecorded ferns from Myanmar flora collected from Natma Taung National Park, Chin State. In 2017, a more comprehensive flora of lycophytes and ferns was published by
Khine et al. (2017), who reported 299 species from 72 genera and 24 families collected from northern and northwestern Myanmar. That study also investigated Natma Taung National Park from an elevation of $400 \mathrm{~m}$ to about 3,000 $\mathrm{m}$ above sea level, reaching the top of Natma Taung Mt., the highest peak in this national park. The authors listed a total of 84 species of lycophytes and ferns from Natma Taung National Park. Considering the area and environmental complexity of the country, a comparison of the flora of lycophytes and ferns of Myanmar with those of Thailand and Vietnam, which exceed 600-700 species (Alston et al., 1939-1951; Tagawa and Iwatsuki, 1979, 1985, 1988, 1989; Boonkerd et al., 2004), suggests that it is likely that many more species than reported to date occur in Myanmar.

Natma Taung National Park in southern Chin State was established in 1994 and is located in western Myanmar, close to the eastern border of Bangladesh with India. The park, which contains the highest peak in southern and central Myanmar,

\footnotetext{
*Author for correspondence: sunby@jbnu.ac.kr
} 
Natma Taung Mt. (elev. 3,051 m), has very rich flora due to its diverse and variable environmental conditions at different altitudes.

Based on a collaboration between the National Institute of Biological Resources (NIBR) of the Ministry of Environment of Korea and the Forestry Department of Myanmar, we conducted three joint floristic expeditions to the park in January and December 2015 and August 2017 to document the lycophytes and ferns in this area. The results will provide valuable information for the Myanmar fern checklist currently in preparation.

\section{Materials and Methods}

Field surveys were performed from 14 to 30 January 2015 and 17 to 29 December 2015 to collect lycophytes and ferns in Natma Taung National Park, Chin State, Myanmar. Each species was identified and its new occurrence in Myanmar was confirmed from the flora records or manuals of adjacent countries, including taxonomic monographs and research papers (Alston et al., 1939-1951; Dickason, 1946; Newman et al., 2007a, 2007b; Fraser-Jenkins et al., 2009, 2015; Nwe, 2009; Lindsay and Middleton, 2013; Wu and Raven, 2013; Sun et al., 2014; Khine et al., 2017). The species were arranged alphabetically by family. Voucher specimens have been deposited in the herbarium of the National Biological Resources Center (KB) of the National Institute of Biological Resources of the Ministry of Environment, Korea.

\section{Results and Discussion}

Three species representing new national records for Myanmar were collected. These species belong to three genera and three families, and were only previously known to be distributed in other countries in Southeast Asia. Fig. 1 shows the general habits of these species. Descriptions and taxonomic comments for each species are provided below.

\section{Dryopteridaceae}

Dryopteris lepidopoda Hayata, Icon. Pl. Formosan. 4: 161162, f. 101, 1914.-TYPE: TAIWAN, Arisan, Jan 1912, Hayata B. \& S. Sasaki s.n. (TI), seen as a photo. (Fig. 1B).

D. lepidopoda var. phaeocoma Ching \& S. K. Wu, Fl. Xizang. 1: 258, 1983.

D. nigra Ching, Bull. Fan Mem. Inst. Biol., Bot. 8: 430431, 1938.

D. taiwanicola Tagawa, Acta Phytotax. Geobot. 8: 230-231,
1939.

Plants terrestrial. Rhizomes erect or suberect, $2.5-3.5 \mathrm{~cm}$ in diam., densely scaly; scales lanceolate to broadly lanceolate, up to $2 \mathrm{~mm}$ long, 1-3 $\mathrm{mm}$ wide, light brown, margins entire, apex long acuminate, slightly hairy on adaxial surface. Fronds clustered; petiole $20-28 \mathrm{~cm}$ long, 3-5 mm in diam., stramineous to light brown, adaxially grooved, densely scaly throughout; scales linear to narrowly lanceolate, up to $1 \mathrm{~cm}$ long, $0.3-1$ $\mathrm{mm}$ wide, dark brown to bicolor, basifixed, margins dentate, apex long acuminate, slightly hairy on adaxial surface, fugacious, leave scar on stipe; blade bipinnate, triangularlanceolate or broadly lanceolate, base truncate, apex acuminate; pinnae up to 25 pairs, $9-14 \times 1.5-2.5 \mathrm{~cm}$ at middle, lanceolate, base truncate, gradually narrow upward, apex acuminate, dark green adaxially, yellowish-green abaxially, glabrous on upper surface, scaly along margins on lower surface, lower 1 or 2 pairs subopposite, alternate upward, pinnatifid; pinnules oblong, 14-20 pairs, 7-11 × 3-5 mm, opposite on both side of costae, margins entire, revolute when dry, apex rectangular with small acute teeth; rachis and costae adaxially grooved, densely scaly; scales narrow lanceolate, brown to dark brown, basifixed, margins dentate, apex long acuminate. Veins free, 2-3 forked, hair like scales on abaxial surface, glabrous adaxially. Sori round, 2 row along the costules, middle on acroscopic side of vein; indusia reniform, thick, margins entire, persistence. Spores trilet, brown.

Specimen examined: MYANMAR. Chin State: Natma Taung National Park, near the top of Victoria Mt., $21^{\circ} 13^{\prime} 35.9^{\prime \prime} \mathrm{N}, 93^{\circ} 54^{\prime 2} 22.9^{\prime \prime}$, elev. 3,042 m, 19 Dec 2015, Sun et al. $2470(\mathrm{~KB})$; along the trail from Victoria Mt. to Mindat, $21^{\circ} 13^{\prime} 05.6^{\prime \prime} \mathrm{N}, 93^{\circ} 57^{\prime} 55.4^{\prime \prime}$, elev. 2,503 m, 19 Dec 2015, Sun et al. $2475(\mathrm{~KB})$.

Distribution: Bhutan, China (Sichuan, Xizang, Yunnan), Taiwan, India, Jamu \& Kashmir, Nepal.

Note: Since this species was described in Taiwan in 1914, it has only been known to be distributed in high mountainous areas in southeastern Asia. This species is widely cultivated in gardens due to its colorful new fronds.

\section{Pteridaceae}

Pteris bella Tagawa, Acta Phytotax. Geobot. 8: 166-167, 1939.-TYPE: TAIWAN, Takao Prov., 22 Jan 1939, Tagawa, M. 2056 (Isotype P), seen as a photo. (Fig. 1A).

P. wangiana Ching, Bull. Fan Mem. Inst. Biol., n.s. 1: 311, 1949.

Plants terrestrial. Rhizomes erect or creeping, $1-1.6 \mathrm{~cm}$ in diam., densely scaly; scales lanceolate, bicolor, dark brown in 

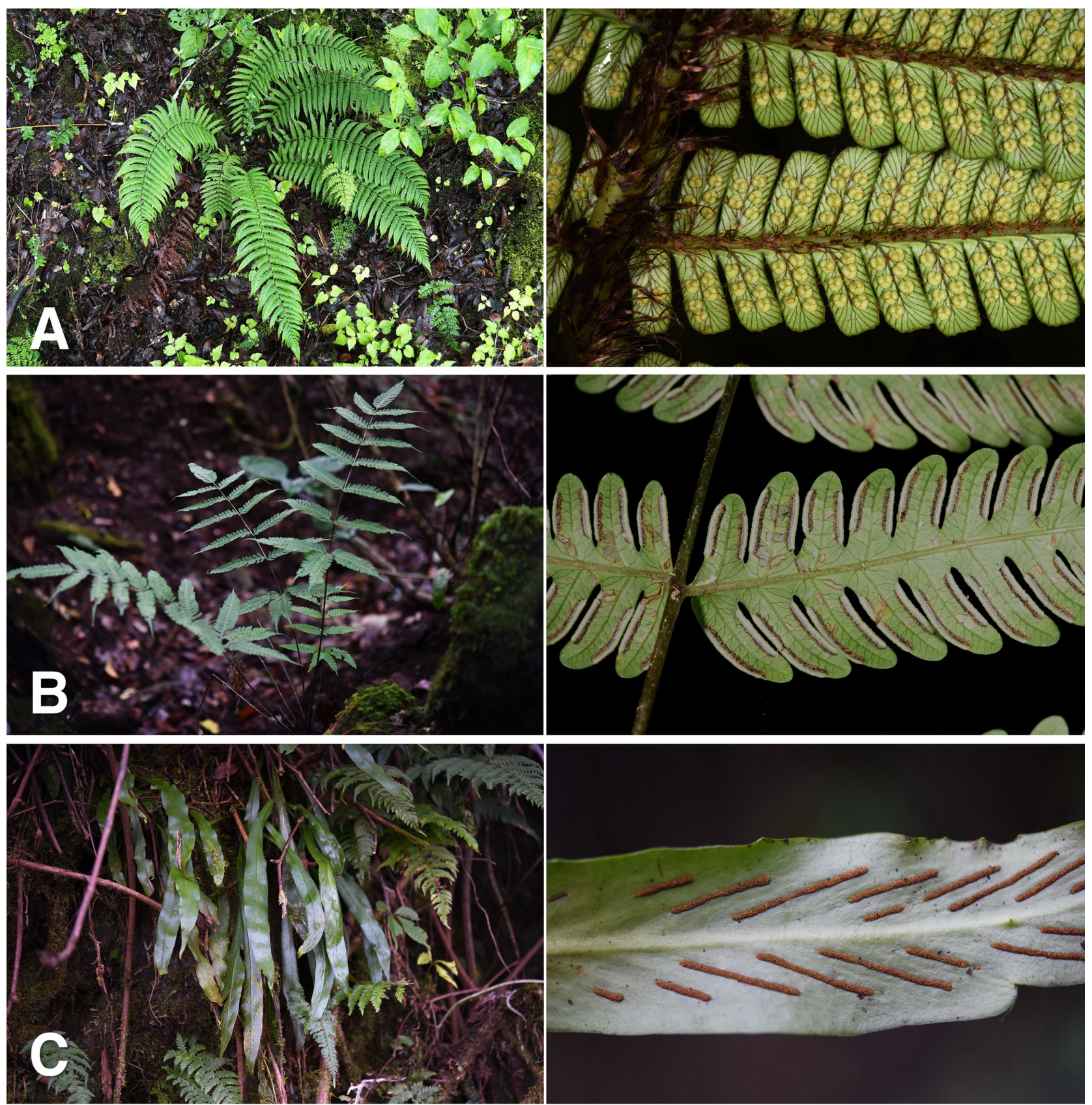

Fig. 1. General habits of ferns new to Myanmar. A. Dryopteris lepidopoda Hayata. B. Pteris bella Tagawa. C. Loxogramme duclouxii H. Christ.

central part, paler laterally on both sides, opaque, margins erose with long multicellular hairs, apex acuminate. Fronds clustered; petiole purple to reddish-brown at base to $1 / 3$ of the petiole, shiny, stramineous upward, $27-51 \mathrm{~cm}$ long, $1.5-4.5 \mathrm{~mm}$ in diam., scaly at base, glabrous upward, catenate hairs throughout; scales similar to the rhizome scale, adaxially grooved; blade bipinnatisect, ovate to oblong, 40-54 × 20$23 \mathrm{~cm}$, imparipinnate; pinnae up to 15 pairs, basal pinnae with
1 pinnule near base of basiscopic side, similar but smaller than main part of pinnae, other pinnae similar in shape, basal 1-3 pairs of pinnae with short stalk, oblong, 10-14 × 1.5-2.5 cm, subopposite to slightly alternate, base round-cuneate, margins deeply lobed near costae, apex long acuminate; segments up to 25 pairs, alternate, close to each other, oblong, 10-15 $\times 2.4$ $3.5 \mathrm{~mm}$, margins entire, apex round, glabrous; rachis and costae stramineous on both sides, sometimes purplish to stramineous 
abaxially, densely catenate hairs at the junction of rachis and costae, sparsely hairy throughout, grooved adaxially, terete abaxially, with distinct long spine at base of costae and costules, spines up to $1.5 \mathrm{~mm}$ long. Veins forked, conspicuous, raised abaxially. Sori marginal; false indusia thin, pale brown. Spores trilet, reddish brown.

Specimen examined: MYANMAR. Chin State: Natma Taung National Park, along the valley near hydroelectric power plant at Kameplet, $21^{\circ} 42^{\prime} 33.0^{\prime \prime} \mathrm{N}, 93^{\circ} 27^{\prime} 56.6^{\prime \prime} \mathrm{E}$, elev. 1,327 m, 22 Dec 2015, Sun et al. 2539, 2553 (KB); under the forest from Kampelet to Victoria Mt., $21^{\circ} 15^{\prime} 11.11^{\prime \prime} \mathrm{N}, 93^{\circ} 56^{\prime} 37.61^{\prime \prime} \mathrm{E}$, elev. 2,328 m, 16 Jan 2015, Sun et al. 2321 (KB).

Distribution: China (Hainan, Hunan, Yunnan), Taiwan, Thailand, South Vietnam.

Note: This species is widely distributed on lower mountain slopes in Southeast Asia. In Natma Taung National Park, it is relatively common at elevations from $1,300 \mathrm{~m}$ to $2,500 \mathrm{~m}$. However, it has not been reported from Cambodia or Lao People's Democratic Republic.

\section{Polypodiaceae}

Loxogramme duclouxii H. Christ, Bull. Acad. Int. Géogr. Bot. 17: 140, 1907.-TYPE: CHINA, Yunnan, Dec 1905, Christ, H. no. 53. (Fig. 1C).

L. saziran Tagawa ex M. G. Price, Am. Fern J. 80: 7, f. 4, 1990.

Plants epiphytic. Rhizomes long creeping, 3-4 mm in diam., densely scaly; scales shiny golden-brown to black, ovatelanceolate to broadly lanceolate, $5-8 \times 2-3 \mathrm{~mm}$, margins entire, apex caudate, clathrate. Fronds simple, slightly dimorphic; petiole up to $3 \mathrm{~cm}$ long, base dark purple brown, scaly at base, glabrous upward; blade coriaceous, thick and fleshy, oblanceolate, $18-28 \times 2-3 \mathrm{~cm}$, gradually attenuate toward base, widest at middle, apex acuminate, margins entire, revolute when dry, glabrous, upper surface deep green, paler beneath; costae obviously raised on adaxial surface, slightly flattened on abaxial surface. Veins invisible, anastomosing to form elongate areoles with included veinlet. Sori linear, $1 / 2$ to $2 / 3$ of the lamina, 0.9-2.7 cm long, oblique, close to each other, superficial; exindusiate. Spores monolete, elliptic, light yellow.

Specimen examined: MYANMAR. Chin State: Natma Taung National Park, Victoria Mt., along the trail from Kamplet to Mindat, $21^{\circ} 13^{\prime} 20.6^{\prime \prime} \mathrm{N}, 93^{\circ} 58^{\prime} 33.4^{\prime \prime} \mathrm{E}$, elev. 2,460 m, 16 Jan 2015, Sun et al. 2116 (KB); near Kampelet, watershed, under

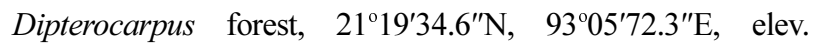
2,250 m, 25 Jan 2015, Sun et al. 2446 (KB).
Distribution: China, India, S Japan to Taiwan, Korea, Thailand, Vietnam.

Note: This species is widely distributed in tropical Asia but extends to the Korean peninsula (Jeju Island). It is closely related to L. salicifolia but differs in the color of its petiole and shape of its fronds. Fraser-Jenkins et al. (2015) treated this species as being conspecific with $L$. cuspidata, while $\mathrm{Wu}$ and Raven (2013) treated it as a different species.

ORCID: Myung-Ok MOON https://orcid.org/0000-0001-5998740X; Seung-Hoon LEE https://orcid.org/0000-0002-32960124; Byung-Yun SUN https://orcid.org/0000-0002-9695-4524

\section{Acknowledgments}

This work was supported by a grant from the National Institute of Biological Resources (NIBR), the Ministry of Environment (MOE) of the Republic of Korea (NIBR201804201).

\section{Conflict of Interest}

The authors declare that there are no conflicts of interest.

\section{Literature Cited}

Alston, A.-H.-G., C. Christensen and M. L. Tardieu-Bolt. 19391951. Cryptogrames Vasculaires. In Flore Générale de L'IndoChine. Gagnepain, F. (ed.), Masson et Cie, Paris. Pp. 1-600.

Bell, P. S. 1953. The ferns and fern allies of Rangoon-Insein Area. Journal of the Burma Research Society 36: 1-70.

Boonkerd, T., S. Lindsay, D. J. Middleton and S. Suddee. 2004. Additions to the pteridophyte flora of Thailand. Thai Forest Bulletin (Botany), Thailand 32: 6-11.

Dickason, F. G. 1946. The ferns of Burma. Ohio Journal of Science 46: 109-141.

Fraser-Jenkins, C. R., S. Matsumoto and T. Wangdi. 2009. Pteridophytes of Bhutan: A List of Families, Genera and Species: ix. National Biodiversity Centre, Ministry of Agriculture, Serbithang, Thimphu, $125 \mathrm{pp}$.

Fraser-Jenkins, C. R., D. R. Kandel and S. Pariyar. 2015. Ferns and Ferns Allies of Nepal. Vol. 1. National Herbarium and Plant Laboratories, Department of Plant Resources, Kathmandu, $492 \mathrm{pp}$.

Khine, P. K., C. Fraser-Jenkins, S. Lindsay, D. Middleton, G. Miehe, P. Thomas and J. Kluge. 2017. A contribution toward the knowledge of ferns and lycophytes from northern and northwestern Myanmar. American Fern Journal 107: 219-256. 
Kurz, S. 1877. Forest Flora of British Burma. Office of the Superintendent of Government Printing, Calcutta, 613 pp.

Lindsay, S. and D. J. Middleton. 2013. Ferns of Thailand, Laos and Cambodia. Retrieved Aug. 1, 2016, available from http:// rbgweb2.rbge.org.uk/thaiferns/.

Merrill, E. D. 1941. The upper Burma plants collected by captain F. Kingdon Ward on the Vernay-Cutting expedition, 1938-39. Brittonia 4: 20-188.

Newman, M., P. Thomas, S. Lanorsavanh, S. Ketphanh, B. Svengsuksa and V. Lamxay. 2007a. New records of angiosperms and pteridophytes in the flora of Laos. Edinburgh Journal of Botany 64: 225-251.

Newman, M., S. Ketphanh, B. Svengsuksa, P. Thomas, K. Sengdala, V. Lamxay and K. Armstrong. 2007b. A Checklist of the Vascular Plants of Lao PDR. Royal Botanic Garden Edinburgh, Edinburgh. Pp 1-33.

Nwe, T. Y. 2009. Diversity of ferns and its identification in Kyaikhti-yoe Wildlife Sanctuary. PhD dissertation, Yangon University, Yangon, Myanmar, 146 pp.

Nwe, T. Y., M.-O. Moon, I. C. Hwang, S.-H. Lee and B.-Y. Sun. 2016. New records of ferns in the flora of Myanmar found in Natma Taung National Park in the Chin State. Korean Journal of Plant Taxonomy 46: 283-287.

Sun, B.-Y., I.-C. Hwang, M.-O. Moon and K. Nang. 2014. Biodiversity of Cambodia: Lycophytes and Ferns. National Institute of Biological Resources, Ministry of Environment, Incheon, $208 \mathrm{pp}$.

Tagawa, M. and K. Iwatsuki. 1979. Pteridophytes. Part 1: Psilotaceae to Dennstaedtiaceae. In Flora of Thailand. Vol. 3. Smitinand, T. and K. Larsen (eds.), Royal Forest Department, Bangkok. Pp. 1-128.

Tagawa, M. and K. Iwatsuki. 1985. Part 2: Lindsaeaceae to Aspleniaceae. In Flora of Thailand. Vol. 3. Smitinand, T. and K. Larsen (eds.), Royal Forest Department, Bangkok. Pp. 129296.

Tagawa, M. and K. Iwatsuki. 1988. Part 3: Blechnaceae to Athyriaceae. In Flora of Thailand. Vol. 3. Smitinand, T. and K. Larsen (eds.), Royal Forest Department, Bangkok. Pp. 297480.

Tagawa, M. and K. Iwatsuki. 1989. Part 4: Dipteridaceae to Azollaceae. In Flora of Thailand. Vol. 3. Smitinand, T. and K. Larsen (eds.), Royal Forest Department, Bangkok. Pp. 481639.

Thet, S. 2003. Hkakhaborazi National Park proposed management plan. Prepared for the Forest Department. Union of Myanmar, Yangon, 68 pp.

Wu, Z. Y. and P. H. Raven. 2013. Flora of China. Vols. 2-3. Lycopodiaceae through Polypodiaceae. Science Press, Beijing and Missouri Botanical Garden Press, St. Louis, MO, 959 pp. 